SHORT REPORT

\title{
Cold related mortality in England and Wales; influence of social class in working and retired age groups
}

\author{
G C Donaldson, W R Keatinge
}

J Epidemiol Community Health 2003;57:790-791

P

ercentage increases in mortality in winter were generally higher among lower than higher social classes in 1970$72,{ }^{1}$ but recent studies show no clear association with regional estimates of deprivation. ${ }^{2}{ }^{3}$ We now assess cold related mortalities (always expressed as a fraction of baseline mortality) among social classes in England and Wales, in working and retired age groups, to look for any current effects of social class, and to see whether any such effects are work related.

\section{METHODS AND RESULTS}

Daily deaths 1998-2000 from the Office of National Statistics, for men and women in England and Wales aged 65-74 years and 50-59 years, were extracted by class (when recorded), as 1 (professional), 2 (managerial and technical), 3N (nonmanual skilled), 3M (manual skilled), 4 (partly skilled), or 5 (unskilled), with between 896 and 66477 deaths in each age, sex and class group. Married women with only domestic occupations at home, assigned their husband's class, are classified as housewives. "Central England" temperatures, from the Meteorological Office, were daily means of Squire's Gate Lancashire, Manchester Airport, Malvern, Rothamstead.

Daily mortality at $18^{\circ} \mathrm{C}$ was estimated by generalised linear modelling with Poisson distribution, of mortality on temperature, over the linear range $0^{\circ} \mathrm{C}$ to $18^{\circ} \mathrm{C}$. The regression coefficient of mortality on temperature and its standard error, expressed as percentage of deaths at $18^{\circ} \mathrm{C}$, gave cold related mortality and standard error for each group. A second explanatory variable, mean influenza deaths 10 days before to 10 days after, allowed for influenza. Temperature was lagged three days to give the closest relation to all cause mortality. ${ }^{4}$ Statistical comparisons were assessed by the $t$ test. To minimise problems from multiple comparisons, these were made only between and within classes 5 and 1 .
Cold related mortality in the retired (65-74) age group was generally higher in men of class 5 (unskilled) than class 1 (professional), or other classes, with little difference between men, and women or housewives, of any class (table 1). In the working age group (50-59), women in class 5 had significantly higher cold related mortality than those in class 1 , but in men in class 5 cold related mortality was on average lower than in men of any other class. It was also significantly lower in class 5 among men than women, or housewives who represented $62 \%$ of these women (table 1 ), both in direct comparison and in relation to comparisons of men and women in class 1 .

\section{CONCLUSION}

In men of working age (50-59) cold related mortality was low in class 5 compared with any other class, though it was high in class 5 men of the retired age group (65-74). In the class 5, but not class 1 , men of working age cold related mortality was also low compared with women or housewives of the same class and age group. This implies a beneficial effect of work related factors in men of class 5 but not class 1 , independent of home environment and income. The simplest explanation is that internal heat production from manual work protected class 5 men against daytime cold stress.

International surveys also point to an important role of out of home factors. Cold related mortality in eight regions of Europe varied inversely with the effectiveness of measures taken by the people in the different regions to avoid both outdoor and indoor cold. ${ }^{5}$ Home heating and insulation has received much attention in Britain, but less attention has been paid to out of home factors. We suggest increased emphasis on reducing exposure to outdoor cold stress, in campaigns to reduce winter mortality.

Table 1 Cold related mortalities in 1998-2000; England and Wales, at ages $65-74$ and $50-59$ (as \% change in mortality/ ${ }^{\circ} \mathrm{C}$, and $95 \%$ confidence limits)

\begin{tabular}{|c|c|c|c|c|c|c|}
\hline Class & 1 & 2 & $3 \mathrm{~N}$ & $3 M$ & 4 & 5 \\
\hline \multicolumn{7}{|l|}{ Age $65-74$} \\
\hline Men & $\begin{array}{l}1.196 \\
(0.566 \text { to } 1.827)\end{array}$ & $\begin{array}{l}1.485 \\
(1.183 \text { to } 1.786)\end{array}$ & $\begin{array}{l}1.659 \\
(1.206 \text { to } 2.111)\end{array}$ & $\begin{array}{l}1.399 \\
(1.169 \text { to } 1.629)\end{array}$ & $\begin{array}{l}1.805 \\
(1.495 \text { to } 2.116)\end{array}$ & $\begin{array}{l}1.791 \\
(1.336 \text { to } 2.246)\end{array}$ \\
\hline Women & $\begin{array}{l}1.438 \\
(0.312 \text { to } 2.565)\end{array}$ & $\begin{array}{l}1.413 \\
(1.062 \text { to } 1.763)\end{array}$ & $\begin{array}{l}1.630 \\
(1.267 \text { to } 1.993)\end{array}$ & $\begin{array}{l}1.514 \\
(1.153 \text { to } 1.876)\end{array}$ & $\begin{array}{l}2.038 \\
(1.666 \text { to } 2.410)\end{array}$ & $\begin{array}{l}1.452 \\
(0.960 \text { to } 1.944)\end{array}$ \\
\hline Housewives & $\begin{array}{l}1.428 \\
(0.158 \text { to } 2.697)\end{array}$ & $\begin{array}{l}1.714 \\
(1.137 \text { to } 2.291)\end{array}$ & $\begin{array}{l}1.745 \\
(0.874 \text { to } 2.617)\end{array}$ & $\begin{array}{l}1.974 \\
(1.554 \text { to } 2.394)\end{array}$ & $\begin{array}{l}1.960 \\
(1.403 \text { to } 2.518)\end{array}$ & $\begin{array}{l}2.215 \\
(1.369 \text { to } 3.061)\end{array}$ \\
\hline \multicolumn{7}{|l|}{ Age $50-59$} \\
\hline Men & $\begin{array}{l}0.761 \\
(-0.263 \text { to } 1.785)\end{array}$ & $\begin{array}{l}1.108 \\
(0.603 \text { to } 1.613)\end{array}$ & $\begin{array}{l}2.092 \\
(1.225 \text { to } 2.960)\end{array}$ & $\begin{array}{l}1.285 \\
(0.894 \text { to } 1.677)\end{array}$ & $\begin{array}{l}1.086 \\
(0.522 \text { to } 1.649)\end{array}$ & $\begin{array}{l}0.443 \\
(-0.311 \text { to } 1.197)\end{array}$ \\
\hline Women & $\begin{array}{l}-0.385 \S \\
(-2.040 \text { to } 1.270)\end{array}$ & $\begin{array}{l}0.534 \\
(-0.013 \text { to } 1.080)\end{array}$ & $\begin{array}{l}0.269 \\
(-0.352 \text { to } 0.890)\end{array}$ & $\begin{array}{l}1.324 \\
(0.606 \text { to } 2.042)\end{array}$ & $\begin{array}{l}1.139 \text { to } \\
(0.472 \text { to } 1.807)\end{array}$ & $\begin{array}{l}2.286 \ddagger^{\star *} \\
(1.139 \text { to } 3.432)\end{array}$ \\
\hline Housewives & $\begin{array}{l}0.136 \\
(-2.025 \text { to } 2.296)\end{array}$ & $\begin{array}{l}0.885 \\
(-0.194 \text { to } 1.964)\end{array}$ & $\begin{array}{l}1.165 \\
(-0.726 \text { to } 3.057)\end{array}$ & $\begin{array}{l}1.190 \\
(0.368 \text { to } 2.012)\end{array}$ & $\begin{array}{l}1.838 \\
(0.699 \text { to } 2.976)\end{array}$ & $\begin{array}{l}2.776 \dagger^{*} \\
(0.888 \text { to } 4.664)\end{array}$ \\
\hline
\end{tabular}

Difference from men in same class, ${ }^{*} p<0.05,{ }^{* *} p<0.01$. Men/women or men/housewife difference in class 5 differs from that in class $1,+p<0.05, \neq p<0.01$ $\S p<0.01$ for difference between class 1 and 5 . 


\section{Key point}

- Cold related mortality was generally low in class 5 men of working age (50-59) only, compared with men in other classes, and significantly compared with class 5 women or housewives. It implies a beneficial effect of work related factors, independent of home environment and income. The simplest explanation is that internal heat production from manual work protected against daytime cold stress.

\section{Authors' affiliations}

G C Donaldson, W R Keatinge, Medical Sciences Building, Queen Mary and Westfield College, London, UK

Both authors are guarantors.

Correspondence to: Professor W R Keatinge, Medical Sciences Building, Queen Mary and Westfield College, Mile End Road, London E1 4NS, UK; w.r.keatinge@qmul.ac.uk

Accepted for publication 26 February 2003

\section{Policy implications}

- Physical exertion and other daytime protection against cold stress need emphasis in campaigns to prevent winter mortality.

\section{REFERENCES}

1 McDowall M. Long term trends in seasonal mortality. Population Trends 1981;26:16-19.

2 Shah S, Peacock J. Deprivation and excess winter mortality. J Epidemiol Community Health 1999:53:499-502.

3 Lawlor DA, Harvey D, Dews HG. Investigation of the association between excess winter mortality and socio-economic deprivation. J Public Health Med 2000;22:176-82

4 Donaldson GC, Keatinge WR. Early increases in ischaemic heart disease mortality dissociated from and later changes associated with respiratory mortality after cold weather in south east England. J Epidemiol Community Health 1997;51:643-8.

5 Eurowinter Group. Cold exposure and winter mortality from ischaemic heart disease, cerebrovascular disease, respiratory disease, and all causes, in warm and cold regions of Europe. Lancet 1997;349:1341-6.

\section{THE JECH GALLERY}

Influential women in occupational health Alice Hamilton, MD: gaining visibility for industrial medicine

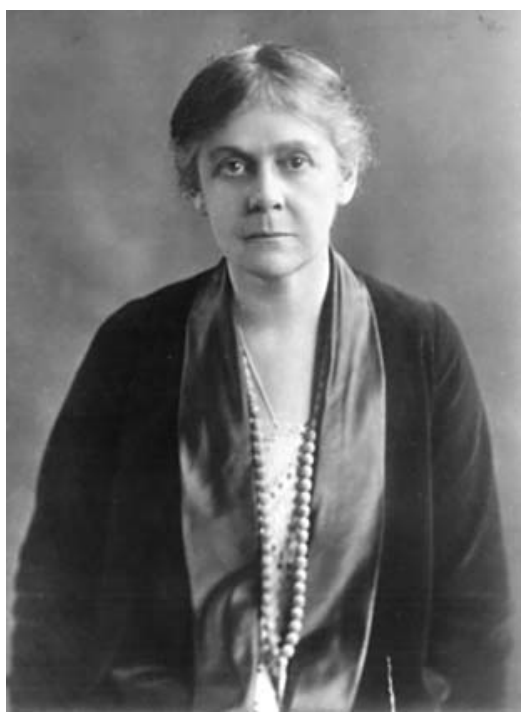

photo credit: Schlesinger Library, Radcliffe Institute, Harvard University.
27 February 1869-22 September 1970

Country of birth: USA

E irst and foremost, Alice Hamilton was an expert on lead. Inside factory walls, she won

- respect-from labour and management-as an effective agent of change, appealing to morality rather than profit. A pioneer in industrial toxicology and an American social activist, Hamilton chaired the first state commission to survey occupational disease, and held the nation's first university appointment in industrial medicine. She brought credibility to a field rife with industrial bias. Her struggles were coupled to a pragmatic nature, lending itself to incremental change.

"For me, the satisfaction is that things are better now, and I had some part of it."

In addition to authoritative work on the dangerous lead trades (for example, smelting, refining, painting, manufacturing), Hamilton conducted studies on mercury, carbon monoxide, rubber, and the munitions industries. In a span of 40 years, she authored over 80 scientific reports. Her pace slowed only in old age (she died at age 101). The US OSHAct was enacted three months after her death in 1970.

The authors gratefully acknowledge the insight and generous contributions of Allen F Davis, Vilma R Hunt, Anne Firor Scott, Barbara Sicherman, and Myron Wegman.

D F Salerno

Pfizer Global Research and Development, Ann Arbor Laboratories, Ann Arbor, MI, USA I L Feitshans Adjunct Faculty, Cornell University, School of Industrial and Labor Relations, Albany, NY, USA Correspondence to: Deborah F Salerno, 2800 Plymouth Road, Ann Arbor, MI 48105, USA;
deborah.salerno@pfizer.com 